\section{SOI: 1.1 /TAS DOI: $10.15863 /$ TAS International Scientific Journal Theoretical \& Applied Science}

\author{
p-ISSN: 2308-4944 (print) e-ISSN: 2409-0085 (online) \\ Year: 2018 Issue: 09 Volume: 65
}

Published: $30.09 .2018 \quad$ http://T-Science.org

\section{Gulnora Sharafitdinovna Karabaeva} senior teacher of the department "Economics of Industry" Tashkent state university of economics, Tashkent city, Republic of Uzbekistan

SECTION 31. Economic research, finance, innovation, risk management.

\title{
ACTUAL ISSUES OF INNOVATIVE DEVELOPMENT OF INDUSTRY
}

Abstract: The article describes the main notions of innovation, conditions industry developments in Uzbekistan, results in recent years. The purpose of the article is to identify the current problems of innovative development of industrial enterprises, to identify the main reasons that impede the development of the process under study.It consideres the factors of innovation development in foreign countries and its possible outlook for domestic industrial enterprises.

Key words: innovations, scientific and technical progress, production, efficiency, production, industry, localization.

Language: English

Citation: Karabaeva GS (2018) ACTUAL ISSUES OF INNOVATIVE DEVELOPMENT OF INDUSTRY. ISJ Theoretical \& Applied Science, 09 (65): 394-398.

Soi: http://s-o-i.org/1.1/TAS-09-65-59 Doi: crossef https://dx.doi.org/10.15863/TAS.2018.09.65.59

\section{Introduction}

In one of his speeches, our first President Islam Karimov stressed: "Domestic science has created a powerful intellectual potential that finds its practical application in many spheres of life, serves as a basis for strengthening the state and economic independence of the republic. We can not imagine our today, and our future without the progress of science and technology. "Thanks to the union of science and technology, called scientific and technological progress, mankind now has modern aircraft, surface and submarine submarines, highspeed rail and road transport, successfully develops space, conducts construction, improves soil fertility, etc. It was the development of science and technology that helped to make an industrial revolution in the late 18 th and early 19 th centuries, to make a number of discoveries in the field of chemistry, physics and natural science. Hence, obviously, comes the well-known among economists thesis about the transformation of science into a directly productive force of society. In our country, special attention is paid to supporting research activities, strengthening the link between science and production, and the formation of an innovation-type economy. This topic, in particular, was also touched upon by our second president at a meeting with American Uzbeks during his visit to the United States. The Head of State noted his benevolent attitude towards those wishing to contribute to the development of our country and urged compatriots, with their potential, knowledge and strength to raise the country's scientific and technical level in the light of large-scale reforms. It was also said that in order to achieve high results in the systemic changes in Uzbekistan, new approaches and new ideas are needed. Without an orientation to scientific and technological progress, without introduction to the production of innovations today, no industry or sphere of economy can do. Products created on an innovative basis not only provide businesses with a long life cycle, but also serves as a kind of entrance ticket to foreign markets. If in the recent past the products with the brand "Made in Uzbekistan" were almost an exception, now it has become almost a rule for the domestic producer. Innovation is ahead of both time and technology.

\section{Literature review}

Issues of innovative economic development have become relevant in recent years and occupy a leading position in the works of foreign and domestic scientists. One of the first questions of innovative economy was engaged I.Shumpeter [1], which actually was the founder of the theory of innovative development. Problems of innovative management are handled by P.A. Fatkhutdinov [2], Yu.P. Morozov [3], L.S. Baryutin [4]. Professor R.A. Fatkhutdinov among the methods of innovation management emphasizes the methods of personnel 
management of the organization aimed at innovation and competitiveness.

Issues related to the analysis of investment and innovation processes have been studied in the works of such authors as S.I. Abramov [5], V. Behrens, G. Birman ,. In recent years, the methodology of American economists Merton, Black and Scholes has spread in the world practice of investing. Of special interest is the theory of F. Agyon, which is based on the modern understanding of the interrelationship of investment and innovation as factors of economic growth, taking into account the non-decreasing returns to scale in innovation and incorporating modern theories of endogenous growth. The study of innovative activity of industrial enterprises involved such domestic scientists as Rasulev AF. [6], Islamova OA, Z.A. Khakimov [7], Vinnikova I.S., Kuznetsova E.A., Repina R.V., Korovina E.A. [9],Nikitin V.V. [10].

At the same time, in the scientific literature, the issues of the interrelationship of investments, innovations and the development of industrial enterprises in aggregate remain insufficiently studied.

\section{Research Methodology}

The methodological basis of the study is a dialectical method of cognition, a systemic and analytical approach that allows us to present scientific studies of socio-economic phenomena and processes in their development, interrelations and interdependence.

\section{Analysis and Results}

According to the existing definitions, innovations are innovations in the field of technology, technology, organization of work and management, based on the use of science and best practices, and the application of these innovations in a wide range of areas and fields of activity. On the basis of innovations, qualitatively new technical means are created, non-waste technology is introduced, and the level of automation of mass production processes is growing. All this in general causes the increase in efficiency not only of material production, but also of the non-productive sphere. The innovation process, from the point of view of the tasks to be solved and the expected results, can be conditionally divided into several stages:

1. Fundamental scientific research and searches;

2. Applied research and development;

3. Technical and socio-economic development of production based on the achievements of science and technology.

Thus, the innovation process today is a single, sequentially interconnected complex: "sciencetechnology-production-consumption". Outside of this scheme, innovations, like any other productive aspirations of economic entities, do not have much practical meaning.

With the aim of deepening and expanding the cooperation of science and production, a unique mechanism has been created, which is realized through the traditional Republican fair of innovative ideas, technologies and projects. It accumulates all the most promising developments of scientists and enables enterprises to establish on their basis the production of technological, competitive products, to raise the domestic production to a qualitatively new level. In 2017, a data bank was created for innovative developments for industry, agriculture, medicine and information technology. The Ministry of Innovative Development of the Republic of Uzbekistan and the Fund for Support of Innovative Development and Innovative Ideas, created pursuant to Presidential Decree No. UP-5264 of November 29, 2017, that play a role of a "bridge" between science and industry, control and promote the introduction of scientific developments into the industrial and commercial environment, finding companies to introduce technologies and investors at innovative exhibitions that are able to finance selected projects. However, with all this, innovations and any other innovations and developments should not be an end in itself and, especially, a temporary phenomenon. Innovation is not only the beginning, but also the result of effective production and economic activity, which is manifested, which is especially important, in addition to novelty and in such properties as production applicability, replicability, influence on lower production costs, productivity growth, etc. Along with this, innovations are important and even necessary on a national scale, especially in conditions when today a decisive course is taken to modernize the country and its withdrawal to the level of the developed countries of the world. Innovations allow, first, to ensure a qualitative breakthrough in the world market of goods and services, secondly, to make the economy more stable and competitive; thirdly, to minimize, and taking into account the prospects, even to eliminate import dependence and to produce domestic products with a high added value cost.

In connection with the announcement in 2018, Year of support of active entrepreneurship, innovative ideas and technologies, comprehensive measures are taken to support this sphere, remove barriers and obstacles to the dynamic and stable development of enterprises.

In the Message of the President Sh. Mirziyoyev, the Oliy Majlis noted that we do not have a carefully planned, long-term unified concept for the formation of investment programs. "We completely abandoned the adoption of fictitious investment programs, hastily designed only for the" tick ". Henceforth, the concepts of long-term development will be developed. To this end, the State Development 
Programs of the Republic of Uzbekistan were adopted as a first step and a Fund for their financing was established. In the development of the economy, one of the important tasks is to involve the population's funds in the form of investments, increase people's interest in entrepreneurship. "[8] With this purpose, it was proposed to open an Internet portal on the Internet that provides local and foreign investors with the necessary statistics and information on the created in the country conditions for doing business. Based on foreign experience, it is necessary for all investors to create a free 24-hour mobile phone connection. We also need to think about the incentive system for foreign investors, so that they do not hurry to withdraw their capital and are eager to reinvest. "As is known, Uzbekistan's textile industry is capable of processing up to 1 million 400 thousand tons of cotton fiber. This is enough to fully meet the raw materials needs of domestic manufacturers of finished products. So far, we have been selling cotton raw materials to domestic textile enterprises only through the joint stock company "Uzpahtasanoat". According to the decree, they will now be able to purchase raw cotton directly from private farms on the basis of direct contracts. Within the framework of the organization of cotton-textile clusters in Navoi, Bukhara and Syrdarya regions, the system of cultivation, pricing and sale of cotton raw materials on the basis of market mechanisms has been approved. However, in managing the processing of cotton fiber, there are still many problems, which leads to a decrease in the profitability of production and processing of raw cotton. And in 9 districts of the country to this day there has not been organized any enterprise with the participation of foreign investments. Direct investments mainly fall on the city of Tashkent, Tashkent, Samarkand and Ferghana Valley. Time itself requires the mastery of this positive experience throughout the country.

Fortunately, for the revival of the innovation spirit, there is no special agitation today. Many enterprises quite clearly realize that innovation is an important way not only for the successful implementation of modernization measures, for the technical and technological re-equipment of production, but also for achieving commercial success, generating high profits or income. And on the national scale, innovation is the basis for carrying out structural changes in the economy, rational allocation and effective use of the existing productive forces, increasing export revenues. By and large, innovations serve progress. On the basis of innovations, it is possible to solve the most ambitious tasks, to give the economy high rates of development, and the produced products-world fame. The industrialized countries that have made innovation a priority for the development of their economy are today taking leading positions in the world in many scientific and technical and economic indicators. According to various estimates, the contribution of innovation to economic growth can fluctuate within $50-70 \%$. So how many world leaders spend on research and development? Statistics show that in percentage terms their share of GDP: 2.98 Japan, 2.69 - USA, 2.48 - Germany, 2.15 - France, 1.87 - Great Britain, 1.84 - Canada, 1, 23 for India, 1.04 for Italy and China and Russia for 1.00 percent. The number of research and development workers per 10,000 population is distributed according to the above-mentioned countries as follows: Japan - 51.0; United States - 41.0; Russia - 34.8; Germany - 31.6; Canada - 29.9; France - 27, 2; Great Britain - 26.7; Italy - 11.3; China and India, respectively - 5.5 and 1.6 people. Today, when our country has not only taken a decisive course towards modernization and renewal, but also has already implemented many things, innovations are changing significantly from simply desired to an objective necessity, into an effective lever for bringing the economy to a qualitatively new level of development. They are reflected in both state and sectoral, regional and other programs that provide for the modernization, localization and diversification of production, deepening the structural transformations of the economy, ensuring its sustainability and competitiveness.

If twelve years ago, thanks to innovations and localization of production, a little more than 30 types of new products were developed, then from 2010 about 2000 localization projects were realized. Over the past three years, the effect of import substitution amounted to more than $\$ 7.5$ billion a year. The share of exports of localized products in the total volume of sold products should reach $20 \%$ in 2018. As a result of an active innovation policy, as well as measures to increase the competitiveness of domestic products and stimulate its promotion to foreign markets, the range of imported goods has been discontinued for more than 100 product groups. At the same time, imports of 350 items of foodstuffs, ferrous and non-ferrous metals, machinery and equipment, construction materials, services, etc., are halved. For example, within the framework of the implementation of the Strategy for the Further Development of the Republic of Uzbekistan in the third direction, "Development and liberalization of the economy" provides for the implementation of measures to strengthen macroeconomic stability and maintain high economic growth rates, increase its competitiveness, modernize and intensify agriculture, continue institutional and structural reforms to reduce the state's presence in the economy, further strengthen the protection of rights and the priority role second property, stimulate the development of small business and private entrepreneurship, integrated and balanced socio-economic development of regions, districts and cities, active 
attraction of foreign investments in the sectors of the economy and regions of the country by improving the investment climate. It is also planned to carry out an active investment policy aimed at modernization, technical and technological renovation of production, implementation of industrial, transport, communication and social infrastructure projects; further modernization and diversification of the industry by transferring it to a qualitatively new level aimed at outstripping the development of high-tech manufacturing industries, primarily for the production of finished products with high added value based on deep processing of local raw materials; mastering the release of fundamentally new types of products and technologies, ensuring on this basis the competitiveness of domestic goods in foreign and domestic markets; the continuation of the policy of stimulating the localization of production and import substitution, primarily consumer goods and components, the expansion of interindustry industrial cooperation [9].

Within the framework of the localization program for 2017-2019, 1146 projects with a total production of competitive import-substituting products are planned at 3.4 billion. dollars. As analysis and observations show, the innovation spirit today permeates all sectors and spheres of the economy. A great contribution here, first of all, is made by scientists of the Academy of Sciences, higher educational institutions, as well as specialists from industry research, design and engineering organizations, scientific and technological centers and institutes. Thus, the number of developments and contracts for January-September of 2017 amounted to 4324 , including contracts-3105. The amount of contracts for 2008-2016 is $-112,632.85$ million soums. Uzbekistan plans to increase the share of the information and communication technologies sector in the gross domestic product within five years to $4 \%$. According to the forecasts of international experts, in five years the IT market of Uzbekistan will grow by $83 \%$, while the equipment segment will increase by $77 \%$, software - by $145 \%$ and IT services by more than $170 \%$. Within the framework of the Innovation Center Mirzo Ulugbek Innovation Center being created, it is planned to increase the volume of software products exports in the next five years by 10 times to more than $\$ 30$ million.

Given the global trends in the digital economy, Uzbekistan intends to develop new directions, such as big data, cloud computing, robotics and artificial intelligence.

In the framework of the "Electronic Government" system, the issues of standardization of information exchange of state bodies are still not fully resolved.

"Interdepartmental integration of information systems requires a lot of effort and resources. The state bodies pay insufficient attention to digitization of all their departmental data and to create the necessary information systems and databases that automate internal and interdepartmental processes. "In the UN ratings on the development of egovernment and the ratings of the International Telecommunication Union, Uzbekistan has seen a slight improvement in broadband access infrastructure indicators. The Ministry of Finance has developed a joint project with representatives of the World Bank to launch Digital CASA "Digital Uzbekistan", which involves investing in the development of the country's telecommunications infrastructure.

\section{Conclusions and recommendations}

Innovation is, on the one hand, a barrier to the crisis and any other production threats, and, on the other hand, success and further economic, scientific, technical and social prosperity.

However, innovation is not a tribute to fashion. The vitality of innovation largely depends, first, on the innovations themselves and their compliance with the requirements of time and business practices, and secondly, on the sources of financing. The first condition is important and determinative. Financing in the conditions of the market can not be carried out only at the expense of state budget funds. It is necessary to create a new mechanism that relies on the private sector, flexible, maneuverable and responds quickly to the market's requirements and demands for scientific and technological progress. After all, innovations are made not for the sake of innovation, but in the interests of development of production and the economy as a whole. Today we are moving to the path of innovative development aimed at radical improvement of all spheres of life of the state and society.

It should be noted that a number of preferences and preferences adopted in the republic contribute to the innovative development of economic sectors. Thus, scientific organizations that develop innovative projects are granted tax incentives, and funds allocated for these purposes are exempt from paying almost all taxes, except for a single social payment. According to the new provision, scientific institutions carrying out contractual research on orders of enterprises were also exempted from taxes until 2013. The effect of this tax benefit is planned to be extended until 2020. The adoption of the Law of the Republic of Uzbekistan "On Innovations and Innovation Activity", whose draft was developed by the interdepartmental commission in order to implement the roadmap for effective implementation of the Concept of the Administrative Reform of the Republic of Uzbekistan for enhancing innovation activity in solving the country's social and economic tasks and ensuring competitiveness of the national economy. Adoption of this law will speed up the creation, development and commercialization of the 


\begin{tabular}{|c|c|c|c|c|c|c|}
\hline Impact Factor: & $\begin{array}{l}\text { ISRA (India) } \\
\text { ISI (Dubai, UAF } \\
\text { GIF (Australia) } \\
\text { JIF }\end{array}$ & $\begin{array}{l}=1.344 \\
=0.829 \\
=0.564 \\
=1.500\end{array}$ & $\begin{array}{l}\text { SIS (USA) } \\
\text { PИНЦ (Russia } \\
\text { ESJI (KZ) } \\
\text { SJIF (Morocco }\end{array}$ & $\begin{array}{l}=0.912 \\
=0.156 \\
=4.102 \\
=2.031\end{array}$ & $\begin{array}{l}\text { ICV (Poland) } \\
\text { PIF (India) } \\
\text { IBI (India) }\end{array}$ & $\begin{array}{l}=6.630 \\
=1.940 \\
=4.260\end{array}$ \\
\hline
\end{tabular}

results of scientific, scientific, technical and other innovative activities in civil circulation. And this is natural. After all, who is winning in this rapidly developing world? Only a state that relies on a new thought, a new idea, an innovation. Innovation means the future. If we begin today to build our great future, we must do this primarily on the basis of innovative ideas, an innovative approach. [8].

\section{References:}

1. Schumpeter J. (1982) The theory of economic development / J. Schumpeter; trans. with him. VS Avtonomova, MS Lyubsky, A. Yu. Chepurenko. M.: Progress, 1982.-456 p.

2. Fatkhutdinov RA (2002) Innovative management / Fatkhutdinov RA SP: St. Petersburg, 2002. - $400 \mathrm{p}$.

3. Morozov V. (1998) Methods for assessing the quality of investment projects / / The economist. 1998.-№7.- p.81-85.

4. Baryutin LS (2004) Foundations of Innovation Management: Theory and Practice / J1. S. Baryutin; Ed. PN Zvalin, A.K. Kazantsev, J.I. E. Mindeli. - Moscow: Economics, 2004. 518 p.

5. Abramov S.I. (2000) Investing .- Moscow: TsEM, 2000.- 440 p.

6. Rasulev A.F., Trostyanskiy D.V., Islamova O.A. (2015) The development of innovative potential and the trends of innovative activity of enterprises of Uzbekistan's industry // Economic newsletter Donbas, 2015. Vol. 2 (40). -p.49.
7. Khakimov Z.A. (2016) Factors that increase the competitiveness of light industry enterprises. T: Economics and Finance. It's 2016. 116 p.

8. (2017) Strategy of actions for the further development of the Republic of Uzbekistan. Decree of the President of the Republic of Uzbekistan. Collection of legislation of the Republic of Uzbekistan, 2017, No. 4947. URL: http://www.lex.uz/pages/getpage.aspx?lact_id= 3107042.

9. Vinnikova I.S., Kuznetsova E.A., Repina R.V., Korovina E.A. (2016) Topical issues of innovative development enterprises of industrial sector of Russia // Internet-journal "NAUKOVENIE" Volume 8, No. 6, 2016. http://naukovedenie.ru/PDF/54EVN616.pdf.

10. Nikitin V.V. (2016) Influence of innovative processes on competitiveness of regional economy (on the example of the Chuvash Republic)//Humanitarian, social and economic and social sciences. 2016. No. 4. -p. 186-188. 